\title{
Tratamento conservador das lesões parciais e completas do manguito Rotador*
}

Conservative treatment of partial and complete tears of the rotator cuff*

Osvandré Lech'; Cézar Valenzuela Neto ${ }^{2}$; Antônio Severo ${ }^{3}$

\section{RESUMO}

A lesão do manguito rotador é a mais freqüente patologia do ombro. Cerca de 180 pacientes foram tratados conservadoramente nos dois Serviços nos anos de 1996 e 1997. Este grupo recebeu uma ampla gama de tratamentos (apenas medicação, exercícios caseiros, infiltração, fisioterapia, etc.). Este estudo avaliou os resultados do tratamento conservador em 26 pacientes com rupturas parcial e total do manguito rotador. O protocolo consistiu de um programa com 6 meses de duração que incluiu terapia miofascial específica, exercícios ativos assistidos e de fortalecimento dos músculos do manguito rotador e da musculatura axioescapular. Os fatores de inclusão no estudo foram: 1) realizar todo o programa com apenas um reabilitador; 2) não ter recebido infiltração; 3) não ter tido cirurgia prévia; 4) não ter reumatopatia diagnosticada. Seis meses após a alta, dezoito pacientes $(69,22 \%)$ apresentavam resultado satisfatório, enquanto que os demais 08 casos $(30,78 \%)$ foram considerados insatisfatórios e tiveram indicação cirúrgica.

\section{INTRODUÇÃO}

As lesões degenerativas e traumáticas que afetam o manguito rotador (MR) estão entre as mais freqüentes causas de dor no ombro, merecendo uma atenção cada vez maior no diagnóstico e tratamento, sendo considerado hoje patologia que exige equipe multidisciplinar 4 , 32

Nesta virada de milênio, a medicina permitiu um significativo aumento da expectativa média de vida. Além disso, os indivíduos desejam também viver com qualidade de vida, livres de dores do sistema músculo-esquelético, a ponto de permitir a realização de ampla gama de atividades esportivas e outras. A importância

\section{SUMMARY}

The lesion of rotator cuff is the most frequent lesion of the shoulder. Circa 180 patients were conservatively treated in both Clinics during the years of 1976 and 1997. This group of patients received a wide range of treatments (only medication, home exercises, infiltration, physiotherapy, etc). This study evaluated the results of the conservative treatment in 26 patients with partial and total rupture of the rotator cuff. The protocol consisted of a program with duration of 6 months including specific miofascial therapy, assisted active exercises and of strengthening of the muscles of the rotator cuff and axioscapular musculature. The inclusion criteria of the study were: 1) to carry the program with just one reabilitator; 2) no previous infiltration; 3) no previous surgery; 4) absence of diagnosed rheumatopathy. Six months after the end of treatment, eighteen patients $(69,22 \%)$ presented with satisfactory results, while the other 8 cases (30,78\%) were considered not satisfactory and were referred to surgery.

\section{INTRODUCTION}

The degenerative and traumatic lesions involving the rotator cuff $(R C)$ are among the most frequent causes of shoulder pain, deserving increasing attention in the diagnosis and treatment, and is considered today as a pathology that should be treated by a multi-disciplinar team ${ }^{4}, 32$

Presently, a significant increase in life expectancy was seen thanks to the progress of the medicine. Besides that persons want to have a better quality of life, free of muscle-skeleton pains, and able to practice a wide variety of activities related to sport practice and others. The importance of an articulation of the shoulder with

Endereço para correspondência: Osvandré Lech

Rua Independência, 889

99010-041 Passo Fundo RS

Tel (54) 3111933

E-mail: lech@annex.com.br 
de uma articulação do ombro com normalidade funcional assumiu importância maior do que se supõe.

O MR atua para estabilizar dinamicamente e equilibrar a cabeça do úmero em relação à glenóide, enquanto que o grupo muscular axial (deltóide e peitoral maior, etc.) age para mover o úmero: a ruptura do MR pode levar facilmente à perda da função do ombro ${ }^{17,18} \mathrm{em}$ variados graus.

De acordo com Charles Neer, a patologia do MR pode ser classificada em 03 estágios ${ }^{23}$ I ) edema, inflamação e hemorragia da bursa e dos tendões do MR, ocorrendo principalmente em jovens; II ) espessamento da bursa e fibrose dos tendões, ocorrendo em indivíduos entre 25 e 40 anos; III ) ruptura completa do MR, associada com alterações ósseas da cabeça do úmero e do acrômio, ocorrendo em indivíduos acima de 40 anos. Estas rupturas também se classficam quanto à espessura do tendão envolvido (parcial articular, parcial intra-tendínea, parcial bursal, e total), quanto à etiologia (degenerativa ou traumática) ${ }^{23}$. Quanto ao tamanho, a ruptura pode ser pequena (menor que $1,0 \mathrm{~cm}$ ), média (menor que $3,0 \mathrm{~cm}$ ), grande (menor que $5,0 \mathrm{~cm}$ ) ou maciça (maior que $5,0 \mathrm{~cm})^{27}$

A abordagem conservadora em pacientes com síndrome do impacto do ombro é descrita como sendo de grande valor terapêutico em estudos de vários autores ${ }^{7,10,23,32,35}$

O tratamento conservador das rupturas completas do MR pode ser bem sucedido em pacientes sedentários e/ou idosos: porém, o reparo cirúrgico do MR, seja por via aberta ou artroscópica, é a melhor conduta para os indivíduos ativos ou nos casos de dor e fraqueza muscular persistente e evolutiva ${ }^{15}$. Sabe-se que a cicatrização espontânea do tendão do MR é incomum, devido à retração das extremidades rotas ${ }^{8,9}$. Todavia em rupturas parciais pequenas, observa-se proliferação vascular e granulação local; estes achados apoiam a possibilidade de eventual cicatrização espontânea ${ }^{33}$. Brox e cols. constataram que o período de tratamento entre pacientes submetidos à artroscopia e à conduta conservadora era de mesma duração ${ }^{2}$. Torstensen e cols. ${ }^{33}$ defendem que a lesão do MR pode ser tratada conservadoramente através de um programa de exercícios supervisionados com base em controle ecográfico, porém apresentaram escassa casuística.. Burkhart ${ }^{3}$ relatou resultados satisfatórios com tratamento conservador em pacientes com ruptura completa do supraespinhal quando o infraespinhal era normal. Outro estudo ${ }^{10} \mathrm{comparou}$ dois grupos de pacientes (com exercícios e sem exercícios) e concluiu que o tratamento com exercícios foi eficaz para aumentar a função do ombro. Guimarães ${ }^{12}$ tratou conservadoramente 171 casos de síndrome do impacto e de lesão do manguito rotador com termoterapia e exercícios, obtendo resultados satisfatórios em 42,9\% dos pacientes após 01 ano, e 21,5\% após 02 anos. O objetivo deste estudo foi o de avaliar os resultados clínicos e funcionais após um programa de exercícios supervisionados num grupo de pacientes homogêneo. functional normality has increasing importance, nowadays.

The $R C$ acts to stabilize dinamically and to balance the head of the humerus in relation to the glenoid, while the axial muscular group (deltoid and major pectoral, etc) act to move the humerus: the rupture of the $R C$ can easily lead to the loss of the shoulder function ${ }^{17,18}$ in various degrees.

According to Charles Neer, the pathology of $R C$ can be classified in 3 stages $^{23}: 1$ ) edema, inflamation and hemorrage of the bursa and tendons of the $R C$, presenting mainly in young persons; II) thickening of the bursa and tendon fibrosis, occurring in persons between 25 and 40 years old; III) complete rupture of the $R C$, associated to bone alterations of the humerus head and acromium, occurring in persons with more than 40 year of age. These ruptures can also be classified according to the thickness of the involved tendon (partial articular, partial intra-tendon, partial bursal, and total), and also according to the ethiology (degenerative or traumatic) ${ }^{23}$. With respect to the size, the rupture can be small (less than $1,0 \mathrm{~cm}$ ), medium (less than $3,0 \mathrm{~cm}$ ), big (less than $5,0 \mathrm{~cm}$ ) or massive (bigger than $5,0 \mathrm{~cm}$ ) ${ }^{27}$

The conservative approach in patients with syndrome of shoulder impact is described as one of great therapeutic value in studies of several authors 7, 10, 23, 32, 35 .

The conservative treatment of the complete ruptures of $R C$ can be successful in aged or sedentary patients; however, the surgical repair of the $R C$, be it open approach or arthroscopy, is the best choice for active subjects or in those cases of muscular weakness, persistent and progressive ${ }^{15}$. It is known that spontaneous repair of $R C$ tendon is infrequent, due to the retraction of the damaged extremities $^{8,9}$. However, in minor partial ruptures, vascular proliferation and local granulation are seen, what make possible an eventual spontaneous cicatrization ${ }^{33}$. Brox et al. reported that the period of treatment in patients that underwent arthroscopy compared with those treated conservatively had the same duration 2. Torstensen et al. ${ }^{33}$ support that $R C$ lesion can be treated conservatively with a program of supervised exercises controlled by echography, but the casuistic was scarce. Burkhart ${ }^{3}$ reported satisfactory results with conservative treatment in patients with complete rupture of the supraspinatus when the infraspinatus was normal. Another study ${ }^{10}$ compared two groups of patients (with and without exercise) and concluded that treatment with exercises was efficacious to increase the function of the shoulder. Guimarães $^{12}$ treated conservatively 171 cases of syndrome of impact and lesion of the rotator cuff with thermotherapy and exercises, obtaining good results in $42,9 \%$ of patients after one year, and in $21,5 \%$ after two years.

The objective of the present study was to assess the clinical and functional results after a program of supervised exercises in a homogeneous group of patients. 


\section{CASUÍSTICA E MÉTODOS}

Vinte e seis pacientes, 09 homens e 17 mulheres com idades variando entre 34 e 84 anos (média de 61,6 anos), sendo 12 sedentários e 14 considerados ativos, foram incluídos neste protocolo. As queixas consistiam em dor no ombro, região cervical, cintura escapular, e terço proximal e lateral do braço. Destes, 08 (30,76\%) possuíam ruptura completa do MR e 18 $(69,23 \%)$ com ruptura parcial (tabela 1$)$. Ao exame, todos apresentavam arco doloroso e testes "irritativos"de Neer e Hawkins positivos, dor à palpação em pontos de gatilho nos músculos infraespinhal e supraespinhal devido à disfunção miofascial secundária. Além disso, havia diminuição das amplitudes ativa e passiva de movimento devido à dor ${ }^{17}$. O tempo médio de evolução era de 06 meses e todos haviam tentado alguma forma de fisioterapia anteriormente, sem sucesso. A ecografia ou a RNM confirmaram o quadro de ruptura do MR.

O tratamento consistiu de anti-inflamatório não-esteróide via oral, terapia miofascial específica (criocinética, compressão isquêmica e ultra-som nas miogeloses e nos pontos de gatilho), ultra-som contínuo com freqüência de 1,0 Mhz e dosagem de $1,5 \mathrm{~W} / \mathrm{cm}^{2}$ por 05 minutos à região subacromial ${ }^{22}$ ( modelo AVATAR US 873 - KLD Biossistemas Equip. Elet. Ltda.), exercícios de alongamentos em rotação externa em plano de escápula e em adução horizontal a 30 graus de flexão, exercícios de fortalecimento com isométricos (fig. 1), bandas elásticas (fig. 2) e pesos (fig. 3) para rotadores externos e internos do ombro, músculos da cintura escapular (trapézio e serrátil anterior) e deltóide (etapa final) de acordo com protocolo constante no quadro $1^{7,16}$. Nenhum paciente recebeu infiltração com corticóide ou outra terapêutica. O tempo estimado de tratamento foi de 06 meses, com avaliação 06 meses após a alta².

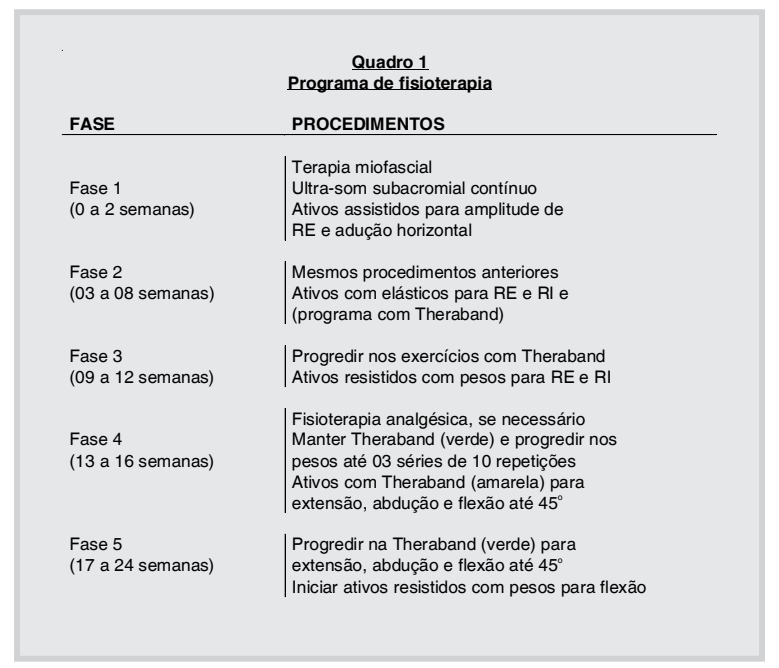

146

\section{MATERIAL AND METHODS}

Twenty six patients, 9 male and 17 female with age between 34 and 84 years old (average 61,6 years), of which 12 with sedentary life and 14 considered active, were included in this study. Complaints were shoulder pain, cervical region, scapular region and lateral proximal third of the arm. From these, 8 (30,76\%) had complete rupture of $R C$ and 18 (69,23\%) had partial rupture (Table 1). Examination showed that all patients had painful arc and positive "irritative" tests of Neer and Hawkins, painful pressure of trigger points of infraspinatus and supraspinatus due to secondary miofascial dysfunction. Additionally there was decrease of passive and active movement amplitude caused by pain ${ }^{17}$. The average time of the condition was 6 months and all had tried before some kind of physiotherapy, without success. The echography or MNR had confirmed the clinical picture of rupture of $R C$.

Treatment was done with oral NSAIDs, miofascial specific therapy (criocinesis, isquemic compression and ultrasound applied to the trigger points), continuous ultrasound with frequency of 1,0 Mhz and dose of 1,5 w/ $\mathrm{cm}^{2}$ for 5 minutes to the subacromial region ${ }^{22}$ (model AVATAR US 873 - KLD Biossistemas Equip. Elet. Ltda.), exercises for stretching in external rotation in shoulder plan and horizontal abduction at 30 degrees of flexion, strengthning exercises with isometrics (Fig. 1), elastic bands (Fig. 2) and weights (Fig. 3) for shoulder external and internal rotators, muscles of the scapular waist (trapesius and anterior serratile) and deltoid (final phase) according to the protocol from Picture 17,16. No patient received infiltration with corticoid or other therapy. The estimated time of treatment was 6 months, with a follow up evaluation 6 months after the end of treatment ${ }^{2}$.

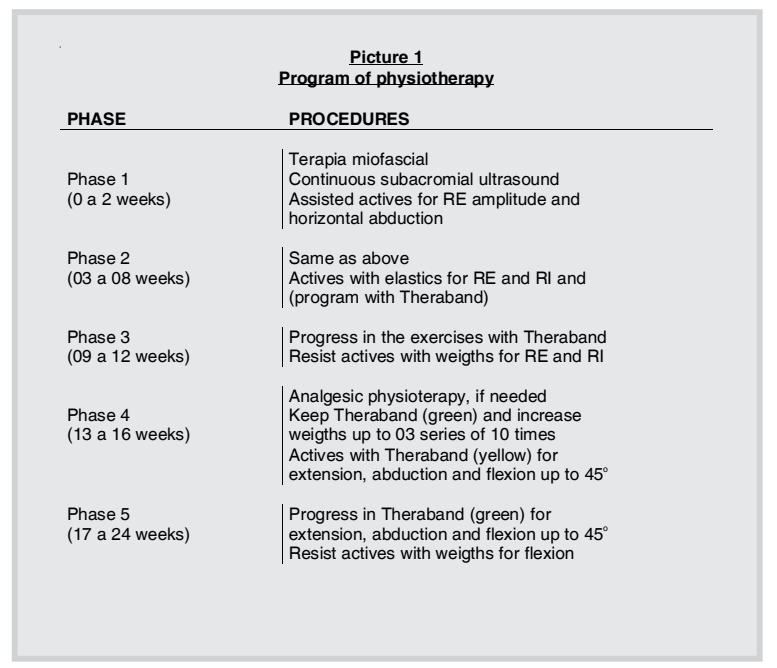

ACTA ORTOP BRAS 8(3) - JUL/SET, 2000 
TABELA 1

Table 1

\begin{tabular}{|c|c|c|c|c|c|c|c|}
\hline No & NOME & IDADE & SEXO & ATIV.PROF. & RUPTURA & PONT.UCLA & RESULTADO \\
\hline 1 & $\mathrm{ROM}$ & 70 & $\mathrm{~F}$ & Não & Parcial & 31 & $\mathrm{~B}$ \\
\hline 2 & $\mathrm{CPR}$ & 69 & $\mathrm{~F}$ & Sim & Parcial & 11 & $\mathrm{M}$ \\
\hline 3 & LDS & 77 & $\mathrm{~F}$ & Não & Completa & 34 & $\mathrm{E}$ \\
\hline 4 & EP & 43 & $\mathrm{M}$ & Sim & Parcial & 34 & $\mathrm{E}$ \\
\hline 5 & NAL & 35 & $\mathrm{~F}$ & Sim & Parcial & 35 & $\mathrm{E}$ \\
\hline 6 & $\mathrm{JM}$ & 79 & $\mathrm{~F}$ & Não & Completa & 28 & $\mathrm{~B}$ \\
\hline 7 & $\mathrm{ZM}$ & 71 & $\mathrm{M}$ & Sim & Completa & 29 & $\mathrm{~B}$ \\
\hline 8 & FSM & 64 & $\mathrm{M}$ & Não & Parcial & 25 & $\mathrm{R}$ \\
\hline 9 & $\mathrm{RMM}$ & 59 & $\mathrm{M}$ & Sim & Parcial & 29 & $\mathrm{~B}$ \\
\hline 10 & MZB & 67 & $\mathrm{~F}$ & Não & Parcial & 16 & $\mathrm{M}$ \\
\hline 11 & LTD & 50 & $\mathrm{~F}$ & Sim & Parcial & 32 & $\mathrm{~B}$ \\
\hline 12 & OT & 68 & $\mathrm{~F}$ & Sim & Completa & 21 & $\mathrm{R}$ \\
\hline 13 & STA & 47 & $\mathrm{M}$ & Sim & Parcial & 28 & $\mathrm{~B}$ \\
\hline 14 & DS & 69 & $\mathrm{~F}$ & Não & Parcial & 34 & $\mathrm{E}$ \\
\hline 15 & ISM & 68 & $\mathrm{~F}$ & Não & Completa & 35 & $\mathrm{E}$ \\
\hline 16 & MRL & 84 & $\mathrm{~F}$ & Não & Completa & 35 & $\mathrm{E}$ \\
\hline 17 & ISS & 48 & $\mathrm{~F}$ & Sim & Parcial & 35 & $\mathrm{E}$ \\
\hline 18 & BAT & 60 & $\mathrm{~F}$ & Não & Parcial & 35 & $\mathrm{E}$ \\
\hline 19 & EM & 60 & $\mathrm{~F}$ & Não & Parcial & 18 & $\mathrm{M}$ \\
\hline 20 & OS & 74 & $\mathrm{~F}$ & Não & Completa & 34 & $\mathrm{E}$ \\
\hline 21 & $\mathrm{AF}$ & 60 & $\mathrm{M}$ & Sim & Parcial & 11 & $\mathrm{M}$ \\
\hline 22 & $\mathrm{NF}$ & 48 & $\mathrm{M}$ & Sim & Parcial & 30 & $\mathrm{~B}$ \\
\hline 23 & $\mathrm{NH}$ & 56 & $\mathrm{M}$ & Sim & Parcial & 12 & $\mathrm{M}$ \\
\hline 24 & $\mathrm{CHS}$ & 48 & $\mathrm{~F}$ & Sim & Parcial & 28 & $\mathrm{~B}$ \\
\hline 25 & LBV & 77 & $\mathrm{~F}$ & Não & Completa & 34 & $\mathrm{E}$ \\
\hline 26 & $\mathrm{HW}$ & 70 & $\mathrm{M}$ & Sim & Parcial & 11 & $\mathrm{M}$ \\
\hline
\end{tabular}




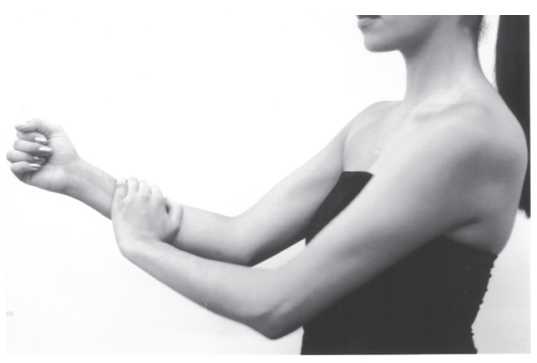

Fig. 1

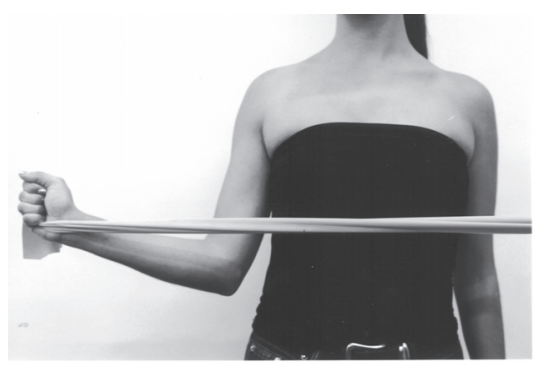

Fig. 2 - B

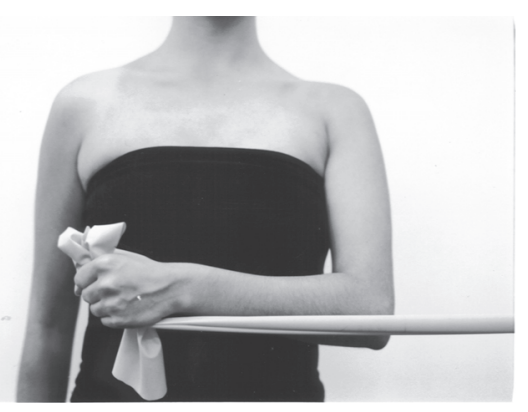

Fig. 2 - A

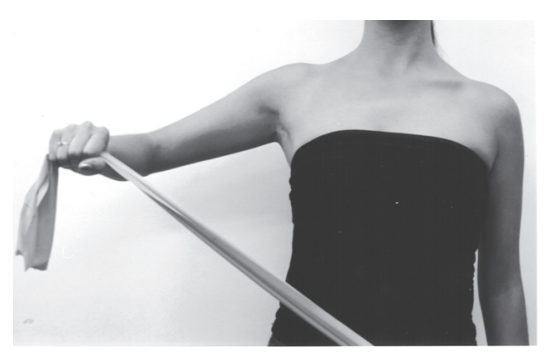

Fig. 2 - C

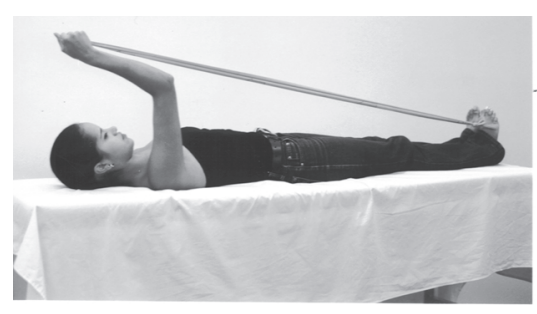

Fig. 2 - D

Fig. 3 - Exercícios com pesos.

a) elevação simples no plano da escápula, impedindo que o MS exceda 70-75 graus de elevação;

b) reforço dos músculos escapulares, que possuem grande importância para a correta rotação da escápula, impedindo o impacto, em posição de decúbito ventral;

c) reforço dos músculos escapulares em posição ortostática (exercícios do "serrote'). 


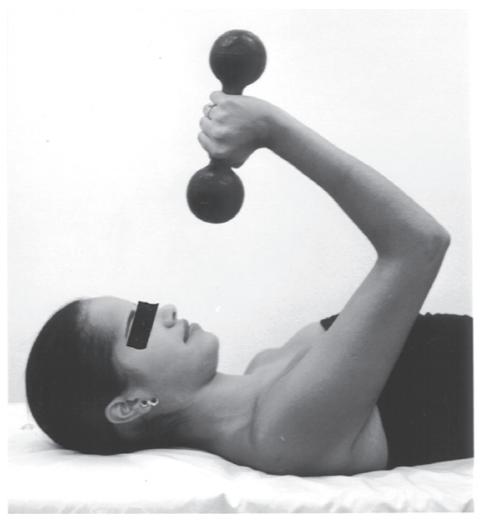

Fig. 3 - A

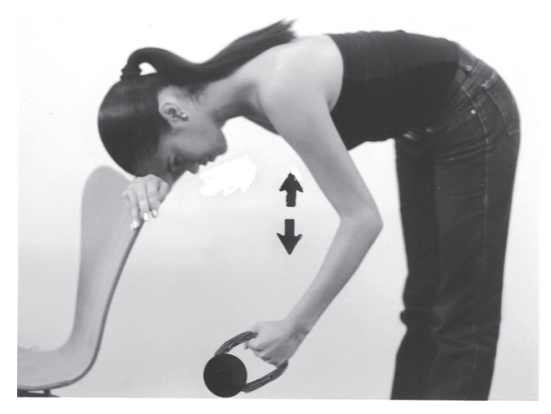

Fig. 3 - C

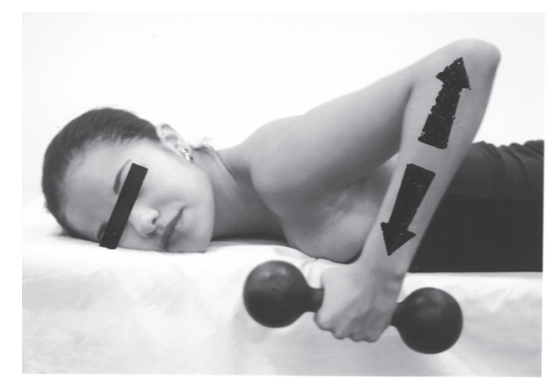

Fig. 3 - B

\section{LEGEND OF THE ILLUSTRATIONS}

Fig. 1 - Isometric exercises for anterior deltoid (the complete series has circa 7 exercises)

Fig. 2 - Exercises with elastic bands.
a) internal rotation;
b) external rotation;
c) lateral deltoid;
d) anterior deltoid.

Fig. 3 - Exercises with weigths.

a) simple elevation to the level of the shoulder, avoiding the $R C$ to exceed 70-75 degrees of elevation;

b) reinforcement of shoulder muscles, which have major importance to the correct rotation of the shoulder, avoiding the impact in the position of ventral decubitus;

c) reinforcement of the shoulder muscles in orthostatic position ("sewer" exercise). 


\section{DISCUSSÃO}

O procedimento de terapia miofascial tem indicação pela resposta satisfatória à inativação dos pontos de gatilho dos músculos correspondentes aos dos tendões rompidos, porém sem a conduta de alongamentos específicos ${ }^{34}$. O supraespinhal e os outros músculos do MR funcionam como estabilizadores e como motores primários da articulação gleno-umeral, garantindo assim que o movimento ocorra em torno de um eixo fisiológico ${ }^{13}$. Estudos biomecânicos e eletromiográficos comprovam a ação principal do MR como sendo de estabilização da articulação gleno-umeral|26, ${ }^{31}$. Durante a abdução ativa do ombro, a cabeça umeral se eleva superiormente em relação à fossa da glenóide devido à contração do deltóide. Os músculos do MR contribuem para a estabilidade articular, gerando uma força resultante oposta à do deltóide, centralizando assim a cabeça do úmero ${ }^{29}$. Jobe ${ }^{16}$ classifica os músculos do MR como protetores da gleno-umeral, os músculos escapulares como pivôs (alinham a escápula para manter o eixo fisiológico), o deltóide como posicionador e o grande dorsal e peitoral maior como propulsores.

Ao movimento de elevação do braço em plano de escápula o infraespinhal contrai-se com 20\% da máxima força isotônica (MFI); já o supraespinhal tem contração constante de $40 \%$ da $\mathrm{MFI}^{25}$. As ações equilibradas e simultâneas do infraespinhal, redondo menor e subescapular limitam com eficácia a translação superior da cabeça do úmero ao produzir um momento em torno da gleno-umeral que auxilia no movimento de elevação do braç ${ }^{24,} 28$.

Burkhart ${ }^{3}$ relatou resultados satisfatórios com tratamento conservador em pacientes com ruptura completa do supraespinhal na presença de um infraespinhal normal, fato este que coincide com os achados do presente estudo.

É possível que o fortalecimento seletivo dos músculos do MR inferior (infraespinhal, redondo menor e subescapular) resulte em aumento da capacidade de resistir à força resultante do deltóide, permitindo uma recuperação da atividade em certos pacientes com ruptura do tendão do supraespinhal ${ }^{20,30}$.

Este conceito é reforçado por outros autores que garantem artrocinemática normal da gleno-umeral em pacientes com ruptura do supraespinhal e contração eficaz dos músculos do MR inferior e dos pivôs da cintura escapular ${ }^{13,21,23}$. Ferreira e cols. ${ }^{7}$ obtiveram $54 \%$ de bons resultados em sua casuística e concluíram que a presença de lesão do manguito rotador acarreta pequena limitação funcional, sendo que nem todas são cirúrgicas e que a fisioterapia deve anteceder à conduta operatória

\section{DISCUSSION}

The procedure of miofascial therapy has its indication due to the satisfactory outcome to the inativation of the trigger points of the muscles corresponding to the ruptured tendons, however without the procedure of specific stretching ${ }^{34}$. The supraspinatus and other muscles of $R C$ work as stabilizers and as primary motors of the glenohumeral articulation, assuring that the movement occurs around a physiological axis ${ }^{13}$. Biomechanical and eletromiographic studies reinforce that the main action of the $R C$ is to stabilize the glenohumeral articulation ${ }^{26,31}$. During the active abduction of the shoulder, the humeral head elevates superiorly in relation to the glenoid fossae due to the contraction of the deltoid. The muscle of $R C$ contribute to articular stability, generating a force opposite to the force from deltoid, centering this way the humerus head ${ }^{29}$. Jobe ${ }^{16}$ classifies the muscles of $R C$ as protectors of the glenohumeral, the shoulder muscles as pivots (they align the scapula to mantain the physiological axis), the deltoid as positioner and the large dorsal and major pectoral as propulsors

During the movement of raising the arm to the level of the shoulder, the infraspinatus contracts with $20 \%$ of its maximum isotonic power (MIP); the supraspinatus has constant contraction of $40 \%$ of MIP25. The balanced and simultaneous actions of the infraspinatus, minor round and subscapular limit with efficacy the superior translation of the humerus head when producing a momentum around the glenohumeral that helps in the movement of raising the arm ${ }^{24,28}$

Burkhart ${ }^{3}$ reported satisfactory results with the conservative treatment in patients with complete rupture of the supraspinatus with a normal infraspinatus, fact that coincides with the findings of this study.

It is possible that the strengthtening of the inferior $R C$ muscles (infraspinatus, minor round and subscapular) result in increased capacity of resisting to the strength resulting from deltoid, allowing a recovery of activity in some patients with rupture of the supraspinatus tendon 20,30 .

This concept is reinforced by other authors that assure normal arthrocynematic of the glenohumeral in patients with rupture of the supraspinatus and efficient contraction of the muscles of inferior $R C$ and pivots of the shoulder ${ }^{13}, 21,23$. Ferreira et al had $54 \%$ of good results in his patients and concluded that the presence of lesion to the RC causes minor functional limitation, not all with indication of surgery and that physiotherapy should precede the surgery.

Guimarães ${ }^{12}$ pointed as causes of bad results the low compliance of patients to exercises and also to the rupture of the $R C$.

Patients with bad results in this study were referred to surgical treatment. The reasons for bad results are many and include: a) non-compliance to the program of exercises; b) overuse of the 
Guimarães ${ }^{12}$ apontou como causas de mau resultado à baixa adesão do paciente aos exercícios e à ruptura do manguito rotador .

Os maus resultados deste estudo foram encaminhados para tratamento cirúrgico. As causas para o mau resultado são múltiplas e incluem: a) não adesão ao programa de exercícios; b) sobreuso do membro afetado; c) persistência da dor. Fukuda ${ }^{8}$ afirma que a maioria dos casos de ruptura parcial envolvendo a superfície bursal do MR não apresentam resultado satisfatório com o tratamento conservador. O fator idade não foi preponderante nem determinante dos casos de resultados bom e excelente. Contudo, o fator ocupação foi mais significativo, pois dos oito casos de resultados mau e regular, seis (75\%) mantinham o mesmo nível atividade profissional.

Também foi confirmado que pacientes com ruptura completa do MR podem apresentar elevação ativa normal do braço, principalmente após um programa de reabilitação com fortalecimento dos músculos pivôs e propulsores da cintura escapular ${ }^{14,19}$.

\section{CONCLUSÕES}

1. Um programa de reabilitação com exercícios supervisionados é eficaz e pode ser considerado como a primeira opção em casos de pacientes com rupturas do MR.;

2. O fator ocupação em pacientes com atividade profissional pode ser indicativo de mau prognóstico com tratamento conservador;

3. A cirurgia pode ser indicada para os casos de dor intensa e que não responde ao programa de tratamento entre 03 a 06 meses. affected member; c) persistence of the pain. Fukuda ${ }^{8}$ states that the majority of cases of partial rupture involving the bursal surface of the $R C$ do not have satisfactory results with the conservative treatment. Age did not influence good and excellent results. However, the occupational factor was more significant, since eight of the cases of bad and regular results, six (75\%) have preserved the same level of professional activity.

It was also confirmed that patients with complete rupture of $R C$ can present with normal active elevation of the arm, mainly after a program of rehabilitation with strengthtening of pivot and propulsive muscles of the shoulder. ${ }^{14,19}$.

\section{CONCLUSIONS}

1. A rehabilitation program with supervised exercises is efficient and can be considered as the first option in patients with rupture of $R C$ :

2. The occupational factor in patients with professional activity can indicate bad prognosis with the conservative treatment;

3. Surgery can be indicated in patients with strong pain and that do not respond to the treatment program in 3 to 6 months. 


\section{RESULTADOS}

Com base no teste de Mann-Whitney ${ }^{9}$, os dados foram analisados de acordo com os seguintes critérios funcionais:

1. Elevação ativa igual ou superior a 135 ;

2. Levar a mão à protuberância occipital externa;

3. Levar a mão à coluna tóracolombar.

Considerando os movimentos descritos acima, os pacientes foram classificados de acordo com o escore abaixo:

- Excelente (E) - Todos os movimentos sem dor;

- Bom (B) - Sem dor espontânea e com 02 movimentos normais;

- Regular (R) - Sem dor espontânea e com dor em 02 ou mais movim.

- Mau (M) - Com dor espontânea e aos movimentos.

Os resultados deste estudo podem ser visualizados nos quadros 1 e 2.

Empregamos também a escala de classificação para ombro - UCLA modificada, assim como o critério de pontuação (quadros 3 e 4 , respectivamente) ${ }^{6}$. A pontuação da casuística deste estudo está expressa na tabela 1.

\begin{tabular}{|llr|}
\multicolumn{4}{c}{ Quadro 2 } & \\
\hline \multicolumn{1}{c}{ Percentuais dos resultados } \\
Resultado & $\mathrm{n}$ & $\%$ do total \\
\hline Excelente $\mathrm{E}$ & 10 & 38,46 \\
Bom B & 08 & 30,76 \\
Regular R & 02 & 7,69 \\
Mau M & 06 & 23,07 \\
\hline $\mathrm{n}=$ número de pacientes & & \\
\hline
\end{tabular}

\section{RESULTS}

Using Mann-Whitney test ${ }^{9}$, data was analysed according to the following functional criteria:

1. Active elevation iqual or superior to $135^{\circ}$;

2. Raise the hand to the external occipital protuberance;

3. Move the hand till the thoracolumbar spine.

Considering the above movements, patients were classified using the scores below:

- Exccelent (E) - All movements without pain;

- Good (G) - Without spontaneous pain and with 2 normal movements;

- Regular (R) - Without spontaneous pain and with pain in 2 or more movements;

- Bad (B) - With spontaneous pain and pain to movements.

The results of this study can be seen in Picture 1 and 2.

A scale for classification of shoulder was also used - UCLA modified, as well as the criteria for scoring (Picture 3 and 4, respectively) ${ }^{6}$. The scoring of this study casuistic is shown in Table 1.

Picture 2

Percent of Results

\begin{tabular}{lrr} 
Result & $n$ & \% of total \\
\hline & & \\
Exccelent E & 10 & 38,46 \\
Good G & 08 & 30,76 \\
Regular $R$ & 02 & 7,69 \\
Bad B & 06 & 23,07 \\
\hline$n=$ number of patients & &
\end{tabular}




\section{Quadro 3 \\ Escala de classificação para ombro - UCLA modificada}

Dor

Presente continuamente, insuportável com freqüente uso de medicação forte

Presente continuamente, mas suportável, medicação forte ocasionalmente

Nenhuma ou pouca dor ao repouso em atividades leves, uso freqüente salicilatos

Presente durante atividades excessivas ou isoladas, uso ocasional de salicilatos

Ocasional ou insignificante

Nenhuma

\section{Função}

Incapacidade de usar o membro

Possível somente em atividades leves

Capaz de realizar tarefas leves ou a maioria de suas atividades diárias

Maioria das tarefas de casa, dirigir, pentear-se vestir ou despir-se

Restrições leves somente. Realizar trabalhos acima do nível do ombro

Atividades normais

\section{Atividades de flexão anterior}

Maior $150^{\circ}$

$120^{\circ}$ a $150^{\circ}$

$90^{\circ}$ a $120^{\circ}$

$45^{\circ}$ a $90^{\circ}$

$30^{\circ}$ a $45^{\circ}$

Menor $30^{\circ}$

Resistência à flexão anterior (teste muscular manual)

Grau 5 - Normal

Grau 4 - Bom

Grau 3 - Moderado

Grau 2 - Ruim

Grau 1 - Contração muscular

Grau 0 - Nenhuma

Satisfação do paciente

Satisfeito ou melhor

Insatisfeito ou pior

Quadro 4

Critérios de pontuação para análise dos resultados

Resultado

\begin{tabular}{l|l} 
Satisfatório & Excelente \\
& Bom \\
Insatisfatório & Moderado \\
& Ruim
\end{tabular}

Pontuação

34 a 35

28 a 33

21 a 27

20 ou menos 
Picture 3

Scale for shoulder classification - UCLA modified

Pain

Continuously present, unbearable, frequent use of strong medication Continuously present, bearable, occasionaly strong medication

No pain or less pain during rest or light activity frequent use of salycilates

Pain during hard activities isolated, occasional use of salycilates

Ocasional or not significant

No pain

\section{Function}

Incapacity to use the arm

Possible only for light activities

Capable of performing light tasks or the majority of daily activities

The majority of home tasks, drive, comb dress or undress

Only few restrictions. Can perform work above the level of shoulder Normal activities

\section{Anterior flexion activities}

Bigger than $150^{\circ}$

$120^{\circ}$ to $150^{\circ}$

$90^{\circ}$ to $120^{\circ}$

$45^{\circ}$ to $90^{\circ}$

$30^{\circ}$ to $45^{\circ}$

Less than $30^{\circ}$

Resistance to anterior flexion (hand muscular test)

Grade 5 - Normal

Grade 4-Good

Grade 3 - Moderate

Grade 2 - Bad

Grade 1 - Muscular contraction

Grade 0 - None

Patient satisfaction

Satisfied or better

Not satisfied or worse

\begin{tabular}{l|ll} 
& \multicolumn{2}{c}{$\begin{array}{c}\text { Picture } 4 \\
\text { Criteria of scoring for results analysis }\end{array}$} \\
\hline Satisfactory & $\begin{array}{lll}\text { Exccelent } & \text { Score } \\
\text { Good } & 34 \text { a } 35 \\
\text { Not satisfactory } & \text { Moderate } & 28 \text { a } 33 \\
\text { Bad } & 21 \text { to } 27 \\
\end{array}$ & 20 or less \\
\hline
\end{tabular}




\section{REFERÊNCIAS}

1. Brox JI, Staff PH, Ljungren AE, Brevik Jl: "Arthroscopic surgery compared with supervised exercises in patients with rotator cuff disease (stage II impingement syndrome)." BMJ, 307: 899-903, 1993.

2. Burkhart SS: "Arthroscopy debridment and decompression for selected rotator cuff tears." Orthop Clin North Am, 24: 111-123, 1993

3. Cofield R: "Rotator cuff disease of the shoulder."J Bone Joint Surg, 67A (6):974, 1985

4. Ellman H, Kay SP: "Arthroscopic subacromial decompression for chronic impingement." J Bone Joint Surg [Br], 73: 395-398, 1991.

5. Ferreira AAF, Greve JMD, Zoppi AF, Bolliger RN, Costa RC Ferreira AAN: "Tratamento conservador da síndrome do impacto do ombro. "Rev. Bras. Ortop, 23:06, 167-169, 1988.

6. Fukuda H, Mikasa M, Yamanaka K: "Incomplete thickness rotator cuff tears diagnosed by subacromial bursography. "Clin Orthop Rel Res, 223:51-58, 1987.

7. Fukuda H, Yamanaka K: "Aging process of the supraspinatus tendon with reference to rotator cuff tears." In: Watson M, ed. Surgical disorders of the shoulder. New York, Churchill Livingstone, 1991.

8. Ginn KA, Herbert RD, Khouw W, Lee R: "A randomized, controlled clinical trial of a treatment for shoulder pain." Phys Ther, 77:08, 802-809, 1997.

9. Guimarães MV: "Avaliação do tratamento conservador do pinçamento subacromial e das lesões do manguito rotador." Rev Bras Ortop, 30:09, 645-648, 1995.

10. Howell S, Imobersteg A, Seger D, Marone P: "Clarification of the role of the supraspinatus muscle in shoulder function."J Bone Joint Surg,68A:398-404,1986

11. Iannotti JP: "Rotator cuff disorders: evaluation and treatment."Am Acad Orthop Surg, Monograph Series, 1991.

12. Itoi E, Tabata S: "Conservative treatment of rotator cuff tears."Clin Orthop, 275: 165-173, 1992.

13. Jobe FW, Pink M: "Classification and treatment of shoulder dysfunction in the overhead athlete."J Orthop Sports Phys Ther, 18:02, 427-432, 1993

14. Kelley M \& Clarck W: "Orthopedic Therapy of the Shoulder." Ed. JB Lippincott Company, 1995.
15. Malone TR, Gwendolin WR, Frick JL: "Shoulder pathology". In: Kelley \& Clarck, Orthopedic Therapy of the Shoulder,JB Lippincott Co.,cap.03,104-157, 1995.

16. Matsen FA, Arntz CT: "Rotator cuff failure."In:Rockwood \& Matsen, Ed. The Shoulder, Philadelphia: WB Saunders, 1990.

17. McLaughlin HL: "Rupture of the rotator cuff."J Bone Joint Surg, 44A: 979-983, 1962

18. McMahon PJ, Debski RE, Thompson WO, Warner JJP, Fu FH, Savio SL-Y: "Shoulder muscle forces and tendon excursions during glenohumeral abduction in the scapular plane."J Shoulder and Elbow Surg, 04: 199-208, 1994.

19. Michlovitz SL: "Thermal Agents in Rehabilitation." aㅡ ed., Philadelphia FA Davis, 1990.

20. Neer, CS II: "Impingement lesions."Clin Orthop,173:70, 1983.

21. Otis JC, Jiang CC, Wickienicz TL e cols.: "Changes in the moment arms of the rotator cuff and deltoid muscles with abduction and rotation."J Bone Joint Surg, 76A: 667-676, 1994.

22. Perry J, Barnes G, Merson J: "Normal electromyographic values of six shoulder muscles during free motion."Orthop Trans, 13:322, 1989

23. Poppen NK, Walker PS: "Normal and abnormal motion of the shoulder."J Bone Joint Surg, 58A: 195-201, 1976.

24. Post M, Silver R, Singhi M: "Rotator cuff tear: diagnosis and treatment."Clin Orthop, 173:78, 1983.

25. Rockwood CA, Williams GR, Burkhead WZ: "Dèbridment of degenerative, irreparable lesions of the rotator cuff."J Bone Joint Surg, 77A:06, 857-866, 1995.

26. Rowe CR: "Ruptures of the rotator cuff: selection of cases for conservative treatment."Surg Clin North Am, 43: 15311540, 1963.

27. Sharkey NA, Marder RA: "The rotator cuff oposes superior translations of the humeral head."Am J Sports Med, 23:03, 270-275, 1995.

28. Sigholm G, Herberts P, Almstrom MC, Kadefors P: "Electromyographic analysis of shoulder muscle load." J Orthop Res, 1:379-386, 1984.

29. Thein LA: "Impingement syndrome and its conservative treatment." J Orthop Sports Phys Ther, 11:05, 183-191, 1989. 
30. Torstensen TA, Meen HD, Stiris M: "The effect of medical exercise therapy on a patient with chronic supraspinatus tendonitis. Diagnostic ultrasound - tissue regeneration: a case study."J Orthop Sports Phys Ther, 20:06, 319-327, 1994.

31. Travell JG \& Simons DG: "Myofascial Pain and Dysfunction - The Trigger Point Manual. Ed. Williams \& Wilkins, vol 1 . caps. 21 e 22, 538-551, 1999.

32. Veado MAC \& Fonseca RMF: "O ombro do nadador veterano." Rev. Bras Ortop, 27:09, 686-690, 1992. 